\title{
Morphological variation in the hyperapolytic lecanicephalidean species Anteropora japonica (Yamaguti, 1934) (Eucestoda)
}

\author{
Rachel R. Guyer ${ }^{1,2}$ and Kirsten Jensen ${ }^{1}$
}

\author{
${ }^{1}$ Department of Ecology and Evolutionary Biology and the Biodiversity Institute, University of Kansas, Lawrence, Kansas, USA; \\ ${ }^{2}$ Department of Entomology and Plant Pathology, University of Tennessee, Jackson, Tennessee, USA
}

\begin{abstract}
In November of 2013, a specimen of Japanese sleeper ray, Narke japonica (Temminck et Schlegel), caught off Nanfang-ao, Taiwan was found to be parasitised by the cestode Anteropora japonica (Yamaguti, 1934). Specimens comprised whole worms and free proglottids, both of varying degrees of maturity. This material allowed for the opportunity to examine in detail the developmental progression of this hyperapolytic lecanicephalidean species with regard to overall size, scolex dimensions, and microthrix pattern. Complete immature worms ranged in size from $2.4 \mathrm{~mm}$ to $14 \mathrm{~mm}$. The smallest scoleces were half as wide as larger scoleces and exhibited a much smaller ratio of apical organ width to bothridial width. Proglottids more than quadrupled in length during maturation from terminal attached immature to detached proglottids. In addition, a change in microthrix pattern was observed on the anterior region of the proglottids from immature to gravid proglottids; the anterior region of attached immature proglottids is covered with gladiate to coniform spinitriches with capilliform filitriches only rarely visible, whereas this region in detached proglottids is covered with gladiate to coniform spinitriches and conspicuous capilliform filitriches. This is the first report of $A$. japonica from outside Japan expanding its distribution south to Taiwan. In addition, a preliminary phylogenetic analysis of the genus is presented that suggests congeners from the same host species are not each other's closest relatives, nor is there an apparent phylogenetic signal for apical organ type or reproductive strategy (apolysis). However, reproductive strategy does seem to be correlated with host group such that euapolytic species parasitise dasyatid stingrays while hyperapolytic species parasitise either torpediniform rays or orectolobiform sharks.
\end{abstract}

Keywords: Lecanicephalidea, Elasmobranchii, Torpediniformes, Narkidae, Narke japonica, Japanese sleeper ray, Taiwan, developmental variation

Anteropora japonica (Yamaguti, 1934) is one of ten valid species of Anteropora Subhapradha, 1955 (see Mojica et al. 2013, Jensen et al. 2016, 2017). Collectively, these ten species parasitise an eclectic suite of elasmobranch hosts, including dasyatid stingrays (Dasyatidae Jordan), torpediniform numbfishes (Narcinidae Gill) and sleeper rays (Narkidae Fowler), and an orectolobiform bamboo shark (Hemiscylliidae Gill), and are restricted to the Indo-Pacific region (Jensen et al. 2011, Mojica et al. 2013).

One of the species, Anteropora comica (Jensen, Nikolov et Caira, 2011), was only recently transferred to the genus (see Jensen et al. 2016) after having been described as the type of the monotypic Sesquipedalapex Jensen, Nikolov et Caira, 2011 in recognition of its highly unusual, extremely elongated apical organ. Among the nine species of Anteropora with an apical organ that is not highly elongated, A. japonica is unique in that it is hyperapolytic and possesses an apical organ that is primarily muscular, rather than primarily glandular.
Furthermore, it is the only member of its genus known to parasitise the Japanese sleeper ray, Narke japonica (Temminck et Schlegel) (Narkidae) (see Yamaguti 1934). Originally reported from off Kuki (Mie Prefecture), Japan, it was subsequently reported, again by Yamaguti (1952), from Maisaka (Sizuoka Prefecture) and Koti (Kochi Prefecture), Japan. It was redescribed by Jensen (2005) based on Yamaguti's type specimens, and voucher specimens, both deposited in the Meguro Parasitological Museum in Tokyo, Japan. However, given those specimens were limited to a series of incomplete worms, strobilar fragments, and detached proglottids, knowledge about the species remains incomplete.

In 2013, a specimen of the Japanese sleeper ray caught off Taiwan was found to host multiple specimens of $A$. japonica, allowing for a more comprehensive description of this cestode species based on complete worms. Herein, A.japonica is redescribed to include new ultrastructural data on scolex and proglottid microthrix patterns for the 
species. In addition, scanning electron microscopy (SEM) was used to characterise microthrix size and distribution on the scolex and proglottids of various stages of developmental progression. Sequence data for the D1-D3 region of the 28S rRNA gene were generated for A. japonica to confirm the conspecificity of specimens spanning the extremely wide range of worm and scolex sizes encountered across the specimens examined, and to place this type species in a phylogenetic context for the first time.

\section{MATERIALS AND METHODS}

A single female individual (unique specimen number: TW62) of the Japanese sleeper ray, Narke japonica, $23.6 \mathrm{~cm}$ in total length, was obtained on 5 November 2013 from a fish market in

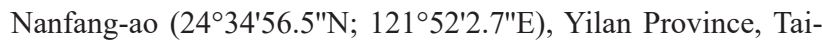
wan, Pacific Ocean. Detailed specimen information is available in the Global Cestode Database (Caira et al. 2019) by searching for the collection code (i.e., TW) and collection number (i.e., 62). The spiral intestine was removed and opened with a longitudinal incision. Worms encountered were fixed in $10 \%$ formalin buffered with seawater for morphological study or $95 \%$ ethanol for generation of molecular sequence data. The spiral intestine was subsequently fixed in $10 \%$ formalin buffered with seawater in the field, and later transferred to $70 \%$ ethanol for storage. Individual worms and free proglottids were prepared for scanning electron microscopy, as whole mounts for light microscopy, and as histological sections following standard protocols (see Mojica et al. 2013). Semi-permanent egg mounts in lactophenol were prepared following Jensen et al. (2011).

Museum abbreviations used are as follows: IPCAS, Institute of Parasitology, Biology Centre, Czech Academy of Sciences, České Budějovice, Czech Republic; LRP, Lawrence R. Penner Collection, Department of Ecology and Evolutionary Biology, University of Connecticut, Storrs, Connecticut, USA; MPM, Meguro Parasitological Museum, Tokyo, Japan; NMMB, National Museum of Marine Biology \& Aquarium, Checheng, Pingtung, Taiwan; USNM, National Museum of Natural History, Smithsonian Institution, Washington, D.C., USA.

All measurements are reported in micrometres $(\mu \mathrm{m})$ unless otherwise stated and are given as the range followed by the mean, standard deviation, number of worms examined, and total number of measurements if more than one measurement was taken per worm. Line drawings were prepared with the aid of a camera lucida attached to a Zeiss Axioskop 2 Plus compound microscope. All measurements were taken using the image analysis software Leica Application Suite Interactive Measurement module on a Zeiss Axioskop 2 Plus. Microthrix terminology follows Chervy (2009). Shape terminology follows Clopton (2004). Batoid taxonomy follows Last et al. (2016). Herein we distinguish between worms with incomplete strobilae (i.e., worms that appear broken with a posterior-most proglottid with straight posterior margin) and complete worms (i.e., worms with terminal proglottid with rounded to pointed posterior margin); given the hyperapolytic nature of Anteropora japonica, all complete worms are immature.

For the molecular work, genomic DNA was extracted from four ethanol-preserved specimens of $A$. japonica: two worms with small scoleces (i.e., scolex widths of 238 and $253 \mu \mathrm{m}$ ) and two worms with large scoleces (i.e., scolex widths of 469 and 473 $\mu \mathrm{m})$. The D1-D3 region of the 28S rRNA gene was amplified and sequenced using primers LSU5 (5'-TAGGTCGACCCGCTGAAYTTAAGCA-3'; Littlewood et al. 2000) and 1500R (5'-GCTATCCTGAGGGAAACTTCG-3'; Olson et al. 2003, Tkach et al. 2003); 1200R (5'-GCATAGTTCACCATCTTTCGG-3'; Lockyer et al. 2003) was used as an internal sequencing primer. The sequences of $A$. japonica were combined with sequence data from GenBank for six of the ten described species of Anteropora, two undescribed species ('Anteropora n. sp. 1' and 'Anteropora $\mathrm{n}$. sp. 2' sensu Jensen et al. 2016), and one specimen identified only to genus ('Anteropora sp.' of Caira et al. 2014 and Jensen et al. 2016). A specimen each of Anthemobothrium sp. 1 and Corollapex n. sp. 1 (as 'New Genus 12 n. sp. 1' in Jensen et al. 2016) were selected as outgroups based on the results of the larger analysis of lecanicephalidean interrelationships of Jensen et al. (2016). Newly generated sequence data were deposited in GenBank; GenBank accession numbers for all specimens follow the specimen number in the tree in Fig. 5.

Contigs were assembled in Geneious 10.2.6. The 15 sequences were aligned in Geneious 10.2.6 using MAFFT version 1.3.7. jModeltest 2.1.7 (Guindon and Gascuel 2003, Darriba et al. 2012) was used to estimate the best-fitting models of nucleotide substitution (TVM $+\mathrm{I}+\Gamma$ ) based on the AIC and AICc. Maximum likelihood (ML) analyses were conducted using the desktop version of Garli 2.01 (Zwickl 2006) as follows: ten independent ML runs were conducted using default settings with the following adjustments: 'genthreshfortopoterm $=100000$ ' and 'significanttopochange $=0.0001$.' ML bootstrap support was estimated using the desktop version of Garli 2.01 by running 100 bootstrap replicates using the same configuration and model as was used for ML analyses with following changes from the default settings: 'genthreshfortopoterm $=10000$ ', 'significanttopochange $=0.01$ ', and 'treerejectionthreshold $=20.0$ '. Bootstrap results were summarised on the 'best' tree resulting from the 10 independent $\mathrm{ML}$ runs using SumTrees 4.0.0 in DendroPy 4.0.3 (Sukumaran and Holder 2010)

\section{RESULTS}

Yamaguti (1934; p. 80) stated that he retained '[t]ype and paratypes' of Anteropora japonica in his collection. This type material, consisting of incomplete worms with scoleces, strobilar fragments, and detached gravid proglottids, is represented by four slides deposited in the Meguro Parasitological Museum (MPM No. 22795 [= SY31-13 to SY31-16]) as stated by Jensen (2005). Accompanying the description were illustrations of two of scoleces and one gravid proglottid (Yamaguti 1934; figs. 122-124); the specimens drawn were indicated on the slides. The figure captions indicate that Yamaguti (1934) designated one gravid proglottid as the holotype and not one of the scoleces, as mistakenly was stated by Jensen (2005; p. 78). Measurements of the type specimens were included in the redescription below and are also given separately for each feature in bold.

\section{Anteropora japonica (Yamaguti, 1934) Figs. 1-4}

Redescription (based on holotype and paratypes MPM No. 22795 [= SY31-13 to SY31-16] consisting of 4 worms with incomplete strobilae, 6 strobilar fragments, and 5 gravid detached proglottids; and newly collected voucher 

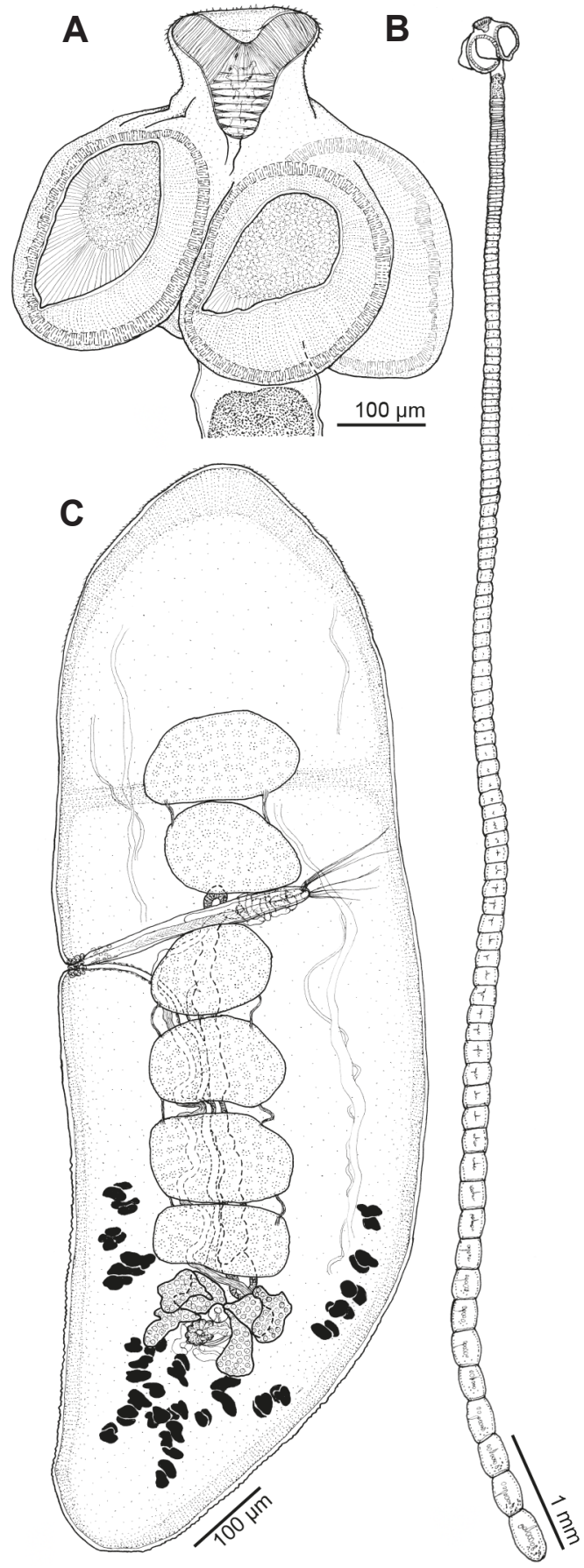

Fig. 1. Line drawings of vouchers of Anteropora japonica (Yamaguti, 1934) from Narke japonica (Temminck et Schlegel) from Taiwan. A - scolex (USNM No. 1604052); B - whole worm (USNM No. 1604051); C - detached mature proglottid (USNM No. 1604055).

specimens consisting of 18 complete worms, 22 detached proglottids [16 mature, 6 gravid]; cross-section series of 1 detached mature proglottid; lactophenol egg preparations of 4 gravid proglottids; and 12 complete worms, 8 scoleces [4 with strobilar vouchers], and 9 detached proglottids prepared for SEM). Complete worms 2.4-14.0 mm (6.6 \pm $3.8 \mathrm{~mm}$; 20) long, with 46-169 (102 \pm 31 ; 24) proglottids, hyperapolytic (Fig. 1B). Scolex 223-534 (361 $\pm 96 ; 28)$ (317-534 [434 \pm 101; 4]) long by 214-671 (378 $\pm 114 ; 28)$
(411-671 [528 \pm 131; 4]) wide, bearing 4 acetabula, and apical structure consisting of apical modification of scolex proper and apical organ. Apical modification of scolex proper pedunculated (Figs. 1A, 2A), non-invaginable, bearing apical organ, with apical aperture (Fig. 2A); apical aperture non-expandable. Apical organ conoid in form, primarily muscular, retractable, non-invaginable, 91-162 $(127 \pm 17 ; 24)$ long by $113-191(148 \pm 22 ; 28)$ (149-172 $[160 \pm 9 ; 4])$ wide. Acetabula bothridiate in form, cupshaped, 132-382 (212 \pm 58; 28; 58) (169-309 [237 \pm 49; 4; 10]) long by 91-278 (171 \pm 51; 28; 56) (146-278 [223 $\pm 47 ; 4 ; 8]$ ) wide.

Apical modification of scolex proper covered with large hastate spinitriches and capilliform filitriches anteriorly (Fig. 2C,J), with gladiate (likely hastate in shape) spinitriches and capilliform filitriches posteriorly (Fig. 2D,K). Distal (Fig. 2E,L) and proximal (Fig. 2F,M) bothridial surfaces covered with narrow gladiate spinitriches and acicular filitriches. Scolex proper covered with acicular to capilliform filitriches (Fig. 2G,N). Proglottids covered with capilliform filitriches and small scolopate spinitriches restricted to posterior margins (Fig. 3G); anterior proglottid region in attached proglottids covered with coniform spinitriches and filitriches not visible in scanning electron micrographs (Fig. 3B) or relatively shorter capilliform filitriches (Fig. 3C); anterior conical (Fig. 3F) or spherical region of detached proglottids covered with coniform spinitriches and conspicuous, long capilliform filitriches (Fig. 3D,E).

Cephalic peduncle absent. Proglottids craspedote, non-laciniate; conspicuous circumcortical longitudinal muscle bundles absent. Immature proglottids 46-169 (102 \pm 31 ; 24) in number, initially wider than long, becoming longer than wide. Terminal immature proglottids (Fig. 3 Aa,b) $118-584(383 \pm 130 ; 28)$ long by 95-241 (162 \pm $35 ; 28)$ wide. Detached mature proglottids (Fig. 3Ac,d) $1.3-2.4 \mathrm{~mm}(1.7 \pm 0.3 ; 16)$ long by $302-533(379 \pm 62 ; 16)$ wide; detached gravid proglottids (Fig. 3Ae, f) $1.6-4.0 \mathrm{~mm}$ $(2.8 \pm 0.8 ; 11) \mathbf{( 2 . 4 - 4 . 0 ~ m m ~ [ 3 . 2 ~} \pm \mathbf{0 . 7} ; \mathbf{5}]$; holotype: $\mathbf{2 . 6} \mathbf{~ m m})$ long by $395-807$ (539 $\pm 139 ; 11)$ (432-807 [592 \pm 169; 5]; holotype: 432 ) wide; anterior end of detached mature and gravid proglottids conical in form (Fig. 3Ad) or forming vacuous spherical region (Fig. 3Af).

Testes generally 6 in number (Figs. 1C, 3A) (1 of 16 detached proglottid with 5 testes $), 63-179(100 \pm 20 ; 16 ; 48)$ long by $65-196(126 \pm 26 ; 16 ; 48)$ wide in detached mature proglottids, in single column anterior to ovary, 1 layer deep in cross-section (Fig. 4B). Vasa efferentia appearing to connect adjacent testes on lateral margins via narrow duct. Vas deferens minimal, sinuous, extending along median line of proglottid from level of posterior margin of ovary to cirrus sac, coiling at level of cirrus sac. External and internal seminal vesicles absent. Cirrus sac narrowly oblong, 156-316 (228 $\pm 48 ; 15)$ long by $23-48(32 \pm 6 ; 15)$ wide in detached mature proglottids, 186-309 (249 \pm 39 ; 10) (186-309 [251 \pm 60 ; 4]; holotype: 186) long and 30$64(50 \pm 10 ; 10)(\mathbf{5 6}-\mathbf{6 4}$ [59 $\pm \mathbf{4} ; \mathbf{4}]$; holotype: 56) wide in detached gravid proglottids, housing cirrus. Cirrus armed, thin-walled. Genital pores lateral, irregularly alternating, 


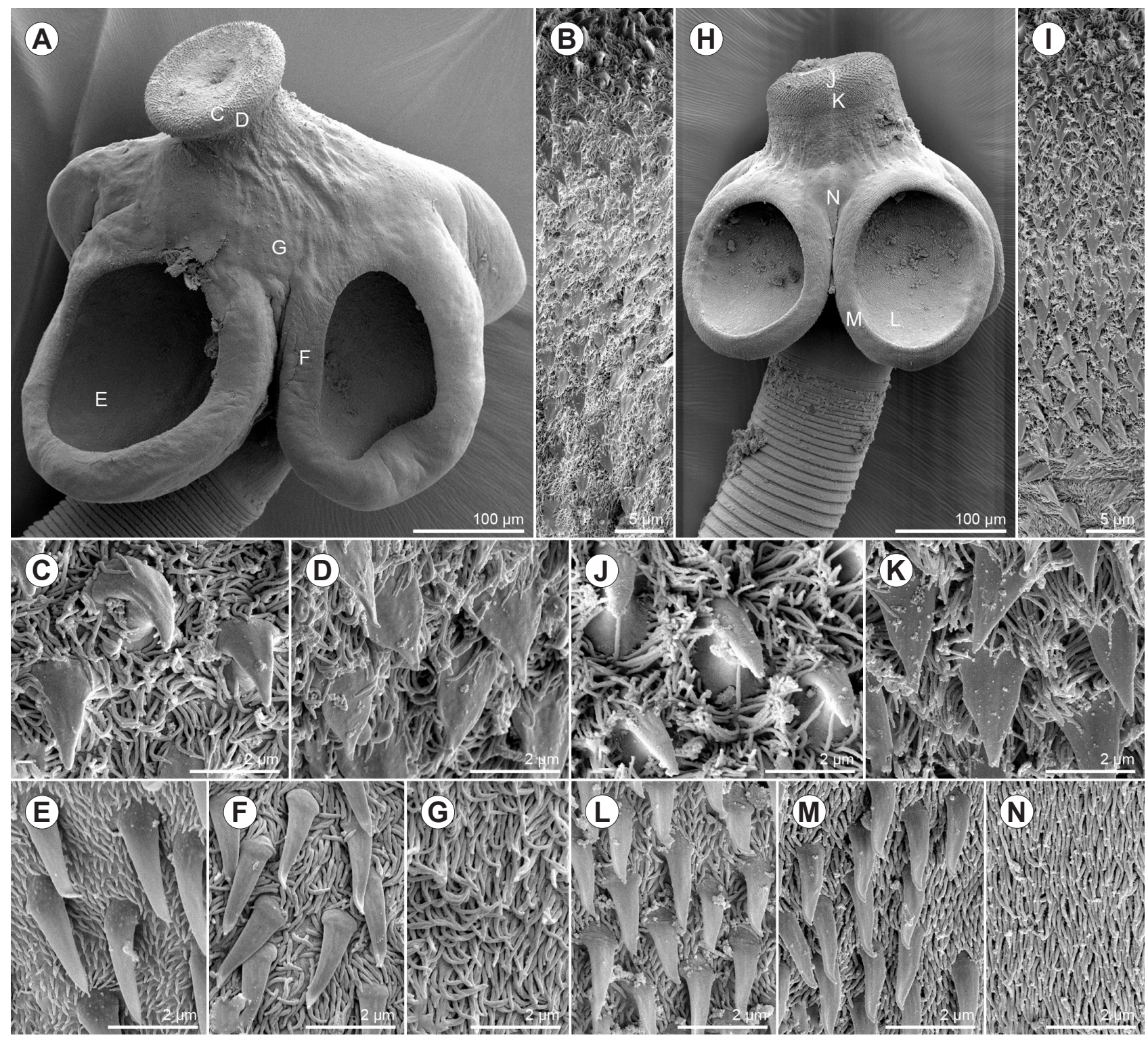

Fig. 2. Scanning electron micrographs of scoleces of Anteropora japonica (Yamaguti, 1934) from Narke japonica (Temminck et Schlegel) from Taiwan. A, H - large scolex (A) and small scolex (H), to scale (small capital letters indicate location of detailed micrographs); B, I - overview of surface of apical modification of scolex proper; $\mathbf{C}, \mathbf{J}$ - surface of anterior of apical modification of scolex proper; D, K - surface of posterior of apical modification of scolex proper; $\mathbf{E}, \mathbf{L}$ - distal bothridial surface; F, $\mathbf{M}$ - proximal bothridial surface; $\mathbf{G}, \mathbf{N}$ - surface of scolex proper.

$49-64 \%(57 \pm 4 ; 16)$ of proglottid length from posterior end in detached mature proglottids; genital atrium shallow.

Ovary essentially $\mathrm{H}$-shaped in dorsoventral view, with 3 lobes on each side, $62-121$ (90 $\pm 20 ; 16)$ long by $88-242$ $(148 \pm 41 ; 16)$ wide in detached mature proglottids, essentially tetralobed in cross-section (Fig. 4A). Vagina thinwalled, medial, opening into genital atrium posterior to cirrus sac; vaginal sphincter absent; seminal receptacle not observed. Uterus saccate, medial, extending from ovary to level of anterior margin of cirrus sac; uterine duct entering uterus at level of genital pore. Vitellarium follicular; vitelline follicles $13-40(24 \pm 7 ; 16 ; 48)$ long by $12-44$ ( $24 \pm 8 ; 16 ; 48)$ wide in detached mature proglottids, in 2 short, irregular lateral bands; each band consisting of 1 to 2 columns, extending from anterior margin of posterior-most testis to posterior margin of proglottid, essentially inter- rupted by ovary, confluent posterior to ovary. Excretory vessels in 2 lateral pairs. Eggs (Fig. 4C) single, 11-18 (14 \pm 2 ; 24) (11-18 [14 \pm 2; 12]; holotype: 11-17 [13 \pm 3; 3]) in diameter, with subequal bipolar filaments; shorter filaments 51-77 (64 \pm 8 ; 15) long; longer filaments 72-103 $(85 \pm 11 ; 15)$ long.

Type host: Japanese sleeper ray, Narke japonica (Temminck et Schlegel) (Narkidae: Torpediniformes).

Type loc a lity: Kuki (Mie Prefecture), Pacific coast of Japan. Additional localities: Maisaka (Sizuoka Prefecture) and Koti (Kochi Prefecture), Pacific coast of Japan (Yamaguti 1952); Nanfang-ao (24³4'56.5"N; 12152'2.7"E), Yilan Province, Taiwan, Pacific Ocean.

Site: Spiral intestine.

Type material: MPM No. 22795 (4 slides: SY31-13 to SY31-16). 

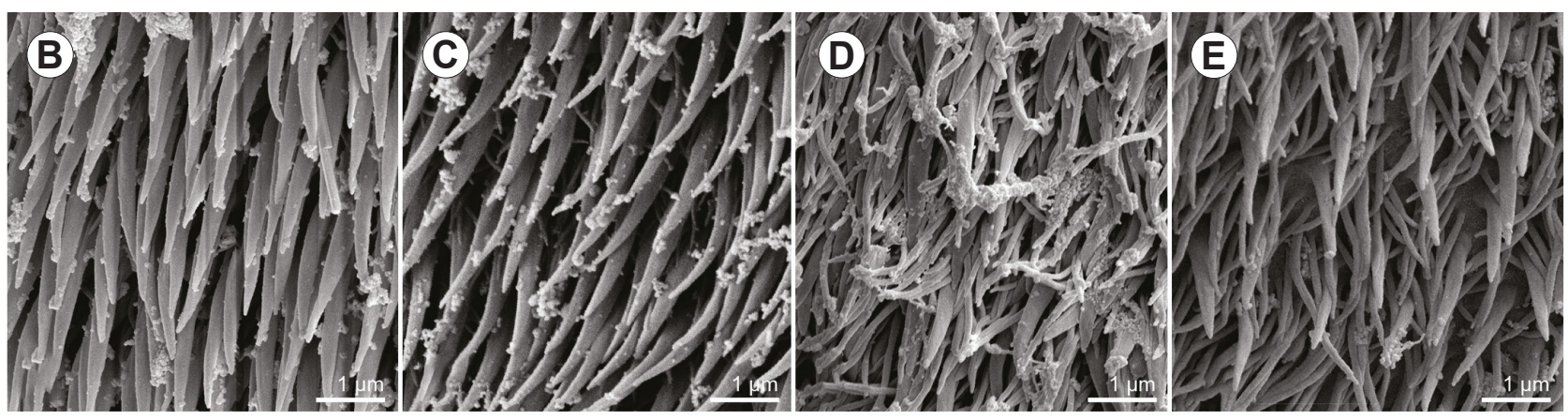

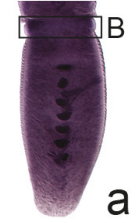

a

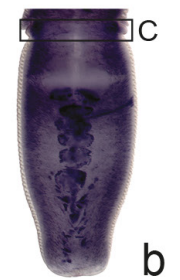

(A)
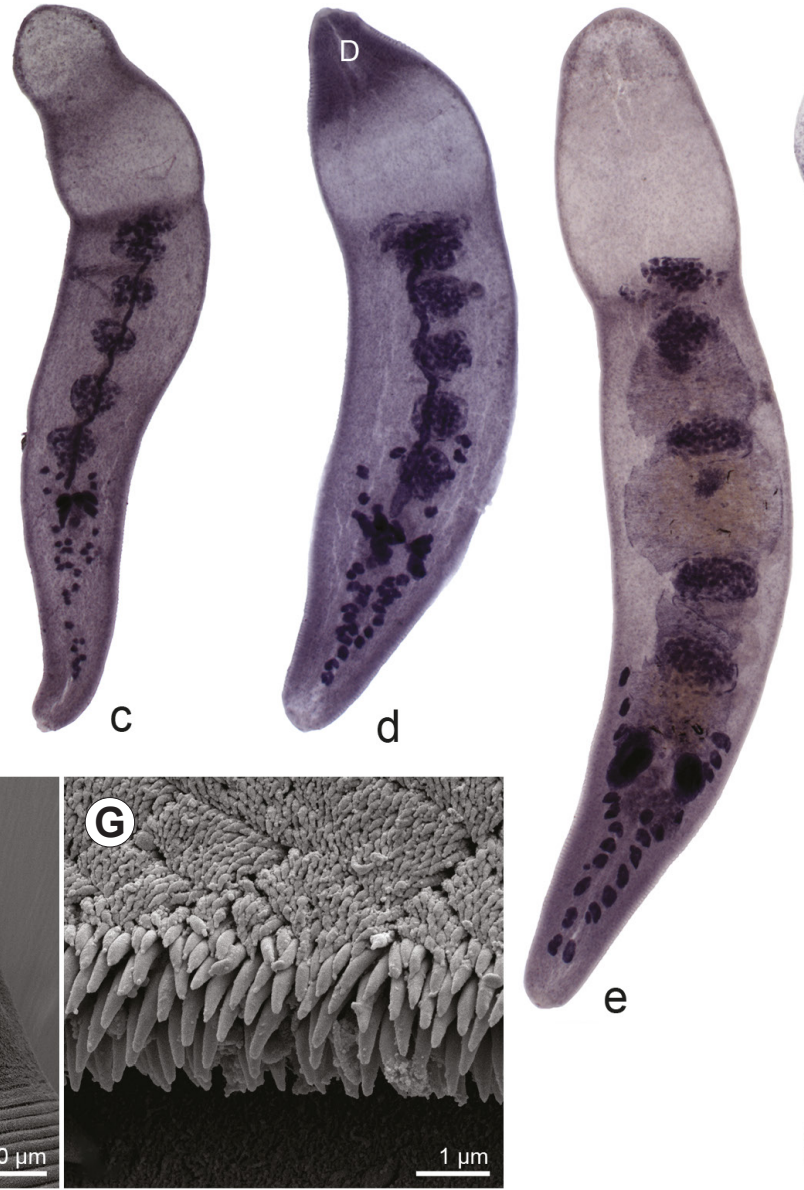

e

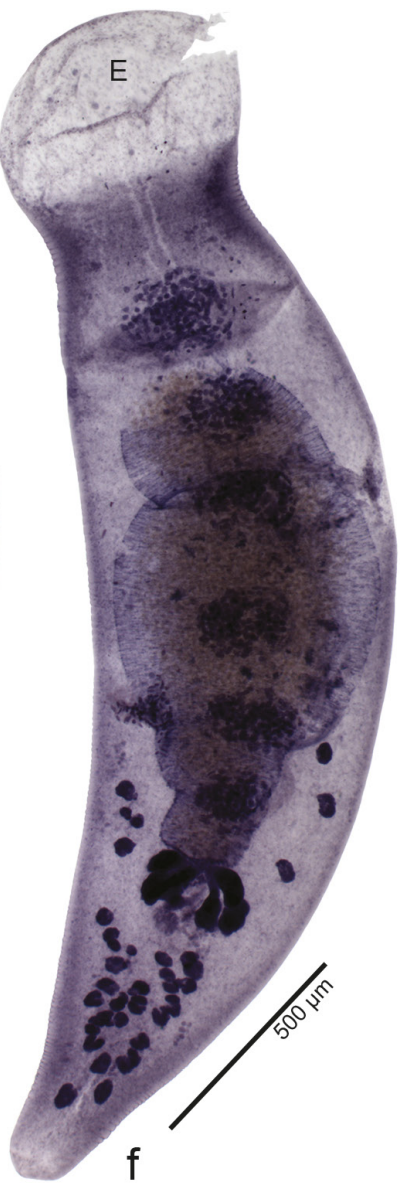

Fig. 3. Scanning electron micrographs and light micrographs of proglottids of Anteropora japonica (Yamaguti, 1934) Euzet, 1994 from Narke japonica (Temminck et Schlegel) from Taiwan. A - light micrographs of attached immature proglottids (a, b), detached mature proglottids with anterior spherical region (c) or anterior conical region (d), and detached gravid proglottids (e, f) showing developmental progression, to scale (small capital letters indicate corresponding location of detailed micrographs); $\mathbf{B}, \mathbf{C}-$ surface of anterior region of attached immature proglottids; $\mathbf{D}$ - surface of anterior region of detached mature proglottids; $\mathbf{E}$ - surface of anterior region of detached gravid proglottids; $\mathbf{F}$ - anterior conical region of detached proglottids; $\mathbf{G}$ - surface of posterior margin of proglottids.

Additional material: From Japan - MPM No. 22892 (2 slides: SY72-75 and SY72-76) (Yamaguti, 1952). From Taiwan - IPCAS Nos. C-828 (1 complete worm, 1 detached mature proglottid, and 1 detached gravid proglottid); LRP Nos. 10021-10050 (8 complete worms, 9 detached mature proglottids, 2 detached gravid proglottids, 2 lactophenol egg preparations, 5 strobilar SEM vouchers, and 4 hologenophores [GenBank Nos. MN701001-MN701004]); NMMB-PL Nos. 000002-000008 (3 complete worms, 2 detached mature proglottids, 1 detached gravid proglottid, and 1 lactophenol egg preparation); USNM Nos. 1604047-1604060 (6 complete worms, 4 detached mature proglottids, 2 detached gravid proglottids, 1 lactophenol egg preparation, and cross-section series of 1 detached mature proglottid). Specimens for SEM retained in the collection of $\mathrm{KJ}$ at the University of Kansas.

\section{Developmental variation}

Substantial, albeit continuous, variation was seen in size across the newly collected specimens, especially with respect to the length of complete immature worms, overall scolex width, length and width of the bothridia, and the ratio of the apical organ to bothridial width. The longest complete immature specimen was over five times longer than the shortest complete immature specimen $(2.4 \mathrm{vs} 14 \mathrm{~mm}$, respectively) with three times the number of proglottids 


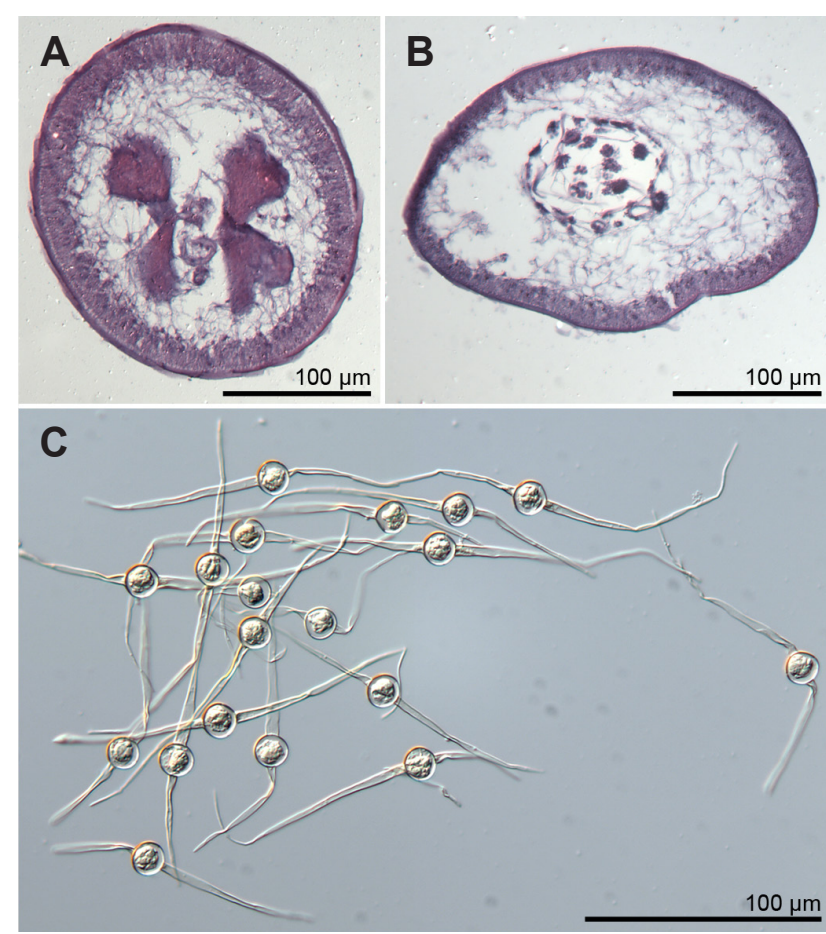

Fig. 4. Light micrographs of Anteropora japonica (Yamaguti, 1934) from Narke japonica (Temminck et Schlegel) from Taiwan. $\mathbf{A}$ - cross-section of detached mature proglottid at level of ovarian bridge; $\mathbf{B}$ - cross-section of detached mature proglottid between ovary and cirrus sac; $\mathbf{C}$ - eggs.

(46 vs 154), but the terminal immature proglottids were of roughly equivalent lengths (353 $\mu \mathrm{m} v s 489 \mu \mathrm{m})$. Bothridia of specimens with larger scoleces (Figs. 1A, 2A) attained a size three times wider and longer than those of specimens with smaller scoleces (Fig. 2H) $(132 \mu \mathrm{m} v s 382 \mu \mathrm{m}$, and 91 $\mu \mathrm{m} v s 278 \mu \mathrm{m}$, respectively). Furthermore, while apical organ width was relative consistent between large and small scoleces (see Fig. 2A,H), the bothridia of specimens with larger scoleces attained twice the width of the apical organ (apical organ width : bothridial width ratio of $1: 2.02$ ) but were narrower or about equal in width to the apical organ in specimens with smaller scoleces (apical organ width : bothridial width ratio of $1: 0.67$ ).

While the microthrix patterns of larger and smaller scoleces differed minimally (e.g., perhaps the gladiate spinitriches on the distal bothridial surfaces were slightly longer in larger than in smaller scoleces - Fig. 2E vs $2 \mathrm{~L}$ ), a more distinct difference in microthrix pattern was observed on the anterior region of attached (i.e., immature) versus detached (i.e., mature or gravid) proglottids. On the anterior region of attached proglottids, filitriches were not readily visible (Fig. 3B) or visible, but relatively shorter (Fig. 3C) than the dense covering of coniform spinitriches. In contrast, on the conoid or spherical anterior regions of detached proglottids, prominent capilliform filitriches were visible among the coniform spinitriches (Fig. 3D,E).

\section{Molecular analysis}

The aligned matrix consisted of 1,269 bp of D1-D3 $28 \mathrm{~S}$ rDNA sequence data. For $A$. japonica, these data were nearly identical among the two specimens with larger scoleces and those with smaller scoleces (Fig. 5). The sequence data of these specimens differed collectively only at four sites. Of these four sites, three had ambiguities in one of the specimens; at the fourth site, two of the specimens (LRP10047 [TW62-1] and LRP10049 [TW62-3]) differed ( $\mathrm{T} v s \mathrm{C}$, respectively) while the remaining two specimens had ambiguities. The ten species of Anteropora included in the analysis formed a monophyletic group. The four specimens of $A$. japonica were found to be deeply nested within this clade of other species of Anteropora included in the analysis (see Fig. 5).

\section{DISCUSSION}

Yamaguti's original description (1934) and redescription (1952), and Jensen's (2005) redescription of Anteropora japonica were thorough and well-illustrated, but they were based solely on a series of incomplete worms and free proglottids. Nonetheless, our understanding of the general scolex morphology and proglottid anatomy of the species was relatively complete, which is surprising given the limitations of the available material. Our examination of a substantial amount of new material from Taiwan has allowed for a more complete morphological characterisation of the species to include data on complete worms, on worms and proglottids of different levels of development, and on microthrix patterns of scolex and proglottids. In addition, while previous records of the species were limited to the waters off southern Japan, this new material extends the geographic distribution of $A$. japonica to include the waters off Taiwan, thus spanning almost the entire longitudinal range of this host species (see Last et al. 2016).

As mentioned by Jensen (2005), Yamaguti's (1952) redescription of $A$. japonica was based on additional material collected from the type host from additional localities in Japan. This material comprised two incomplete worms with scoleces, one strobilar fragment, and a total of 34 detached immature, mature and gravid proglottids. However, these specimens appeared macerated and swollen. Thus, because of the incomplete nature of the worms and their condition, measurements of this material were not included here so as to not artificially inflate some of the measurements (e.g., total length, scolex width, detached mature proglottid length).

Only a few studies have documented an intraspecific change or variation in microthrix pattern. A change in microthrix pattern over the course of development from the plerocercoid stage in the intermediate host to the adult form in the definitive host was documented by Caira and Ruhnke (1991) and Fyler (2007) in the 'tetraphyllidean' Calliobothrium cf. verticillatum (Rudolphi, 1819). Both described a pronounced change in the microthrix pattern on the distal bothridial surface from being covered with densely arranged gladiate spinitriches and acicular to capilliform filitriches in older plerocercoids to these surfaces in adults being covered with sparsely distributed gladiate spinitriches with what we now interpret to be papilliform filitriches. Pickering and Caira $(2012,2013)$ were the first to report intraspecific changes in microthrix patterns in the 


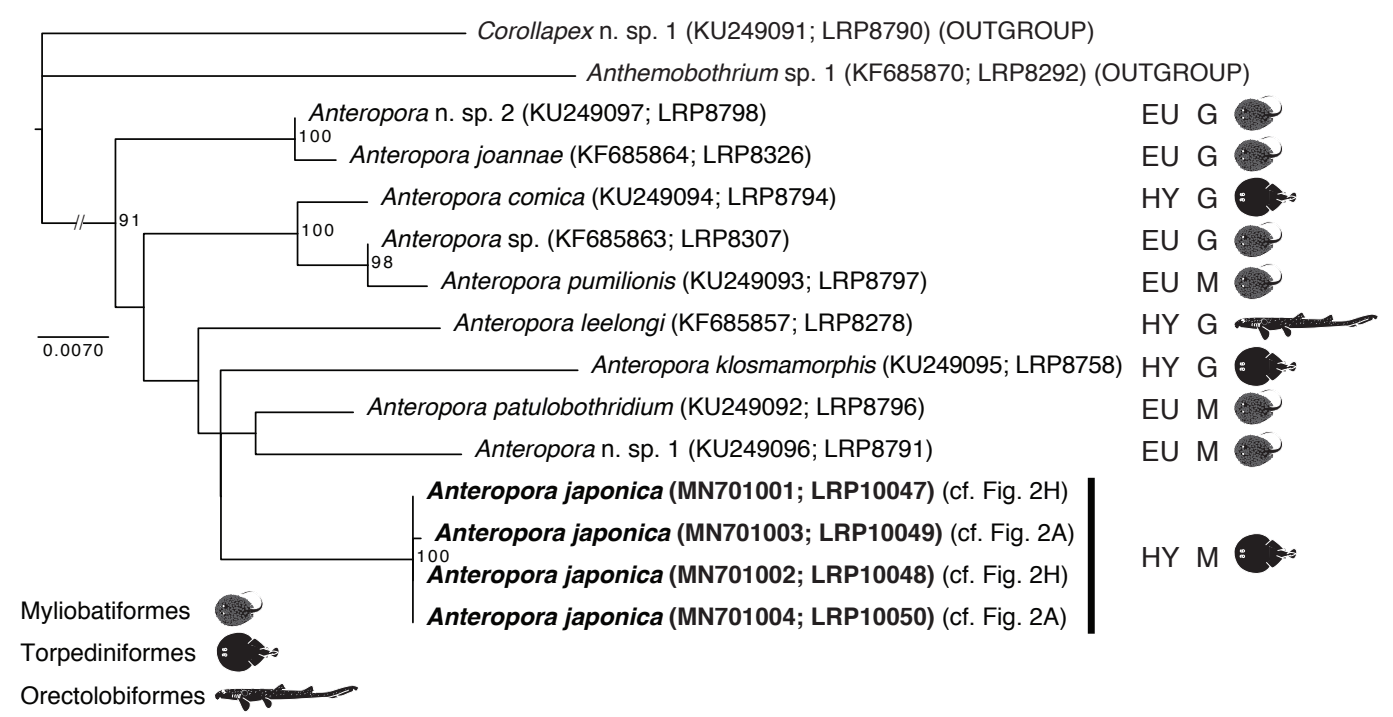

Fig. 5. Phylogenetic hypothesis of interrelationships of a subset of species of Anteropora Subhapradha, 1955, based on Maximum likelihood (ML) analysis of D1-D3 28S rDNA sequence data showing position of Anteropora japonica (Yamaguti, 1934). Taxon names include GenBank and voucher numbers in parentheses. Type of apolysis, type of apical organ and major host group are indicated for each species. Nodal support is given as ML bootstrap values (BS); only BS values above $90 \%$ are shown. Specimens for which new sequence data were generated are indicated in bold. Scale bar indicates nucleotide substitutions per site. Abbreviations: EU - euapolytic; G - primarily glandular apical organ; HY - hyperapolytic; LRP - Lawrence R. Penner Collection, Department of Ecology and Evolutionary Biology, University of Connecticut, Storrs, Connecticut, USA; M - primarily muscular apical organ.

definitive host. The hyperapolytic 'tetraphyllidean' Trilocularia eberti Pickering et Caira, 2012 parasitising dogfish was described to possess gladiate spinitriches covering the anterior attachment region of detached mature proglottids that were twice as long and three times as wide as those covering the anterior attachment region of detached immature proglottids (Pickering and Caira 2012). These same authors, in 2013, also reported variation in spinithrix shape (i.e., scolopate, aristate gladiate, or lingulate spinitriches, or mixtures of scolopate and aristate gladiate or aristate gladiate and lingulate spinitriches) on the proximal bothridial surfaces of a congener of T. eberti, Trilocularia gracilis Olsson, 1867.

Here we document both, a slight difference in the size of the gladiate spinitriches on the distal bothridial surfaces being larger on larger scoleces, and a difference in the microthrix pattern on the anterior region of proglottids during development. While coniform spinitriches are present on the anterior region of attached immature proglottids and detached proglottids of any age, filitriches are either not visible (e.g., papilliform) or visible, but relatively shorter than the coniform spinitriches on the anterior region of attached immature proglottids, and grow or are replaced by capilliform filitriches in that region on detached proglottids. It would be interesting to determine if a similar change is seen in the free proglottids of other hyperapolytic species of Anteropora.

Anteropora is one of the more heterogeneous genera in the Lecanicephalidea with respect to apical organ morphology (primarily glandular $v s$ muscular), apolysis (euapolytic $v s$ hyperapolytic), and host associations (parasitising dasyatid stingrays, torpediniform rays, or orectolobiform sharks). Of the ten described and two undescribed species (i.e., Anteropora n. sp. 1 and Anteropora n. sp. 2 of
Jensen et al. 2016), seven exhibit a primarily glandular and four a primarily muscular apical organ (Anteropora indica Subhapradha, 1955 was described based only on detached proglottids; thus, we cannot determine apical organ condition); seven are euapolytic and five are hyperapolytic; and seven parasitise dasyatid stingrays, four torpediniform rays, and one an orectolobiform shark. While apical organ morphology and apolysis appear not to be correlated (i.e., all four combinations of features are collectively exhibited by species of Anteropora), association of apolysis with host group is not entirely random. Euapolytic species of Anteropora parasitise dasyatid stingrays while hyperapolytic species parasitise either torpediniform rays or orectilobiform sharks. We know of only two other elasmobranch tapeworm genera that parasitise both torpediniform rays and orectolobiform sharks; in both we see a tendency for an association of apolysis with host group. Of the two described species of Pentaloculum Alexander, 1963, Pentaloculum hoi Eudy, Caira et Jensen, 2019, in the Taiwan saddled carpetshark, Cirrhoscyllium formosanum Teng, (Orectolobiformes, Parascylliidae Gill), is hyperapolytic. However, Pentaloculum macrocephalum Alexander, 1963, from the blind electric ray, Typhlonarke aysoni (Hamilton) (Torpediniformes, Narkidae), is euapolytic (Eudy et al. 2019). Only six of the almost 200 valid species of Acanthobothrium (see Caira et al. 2017, Franzese and Ivanov 2018, Maleki et al. 2018, 2019, Rodríguez-Ibarra et al. 2018, Zaragoza-Tapia et al. 2019) are considered to be hyperapolytic (see Franzese and Ivanov 2018). Five of these six hyperapolytic species of Acanthobothrium, namely A. lintoni Goldstein, Henson et Schlicht, 1968, A. indicum Subhapradha, 1955, A. pearsoni Williams, 1962, A. stefaniae Franzese et Ivanov, 2018, and A. margieae Fyler, 2011, do, in fact, parasitise either torpediniform rays or orectolo- 
biform sharks (Subhapradha 1955, Williams 1962, Goldstein et al. 1968, Fyler 2011, Franzese and Ivanov 2018). However, there are two other species of Acanthobothrium in orectolobiform sharks (i.e., A. brayi Campbell et Beveridge, 2002 and $A$. edmondsi Campbell et Beveridge, 2002; Campbell and Beveridge 2002) and 13 additional species of Acanthobothrium in torpediniform rays (Baer 1948, Yamaguti 1952, Riser 1955, Yamaguti 1959, Brooks and Mayes 1978, Marques et al. 1997, Caira and Burge 2001, Campbell and Beveridge 2002, Zaragoza-Tapia et al. 2019), all of which are euapolytic.

Given that hyperapolysis in elasmobranch tapeworms has also been reported in genera parasitising other host groups (e.g., Megalonchos Baer et Euzet, 1962 in carcharhiniform sharks - see Caira et al. 2007, Trilocularia Olsson, 1867 in squaliform sharks - see Pickering and Caira, 2012, 2013), formal examination of this reproductive strategy in a comparative phylogenetic context might shed some light to the evolution of this feature as either being independently evolved in several groups, showing phylogenetic signal, or a combination.

The phylogenetic hypothesis of interrelationships among seven of the ten valid species, and Anteropora n. sp. 1, Anteropora n. sp. 2, and Anteropora sp. is overall consistent with the pattern of interrelationships presented by Jensen et al. (2016). Specimens of $A$. indica, $A$. cuba Mojica, Jensen et Caira, 2013, and A. glandapiculis Mojica, Jensen et Caira, 2013 were not included in the analysis.
Despite the shortcomings of the analysis, some insights in terms of the evolution of apical organ morphology and apolysis, and patterns of host associations in this genus can be drawn. One of the few well-supported clades included A. comica as sister taxon to Anteropora sp. plus A. pumilionis Mojica, Jensen et Caira, 2013. This clade suggests that there is no clear signal for (1) species with primarily muscular $v s$ glandular apical organs being each other's closest relatives, (2) for reciprocally monophyletic clades of hyperapolytic $v s$ euapolytic species, nor (3) for clades of species parasitising hosts of the same order (i.e., Torpediniformes vs Myliobatiformes). Moreover, the data strongly support that congeners from the same host species are not each other's closest relatives. Additional genetic markers are needed to generate a more robust phylogenetic hypothesis to definitively determine intrageneric relationships.

Acknowledgements. We are grateful to Janine N. Caira (University of Connecticut) for comments on earlier versions of this manuscript, as well as for her leading role during our trip to Taiwan. We are also grateful to Maria Pickering (Meredith College) for generating the sequence data for the four specimens of $\mathrm{An}$ teropora japonica used in this project. We are most grateful to Hsuan-Ching Ho (National Museum of Marine Biology \& Aquarium, Checheng, Pingtung, Taiwan) for logistical support during our field work in Taiwan. We thank two anonymous reviewers for their thoughtful comments that improved the manuscript. This project was funded by NSF DEB award nos. 0818696 and 0818823, and DEB 1921404 and 1921411.

\section{REFERENCES}

BAER J.G. 1948: Contributions àa l'étude des cestodes des sélaciens. I-IV. Bulletin de la Société Neuchâteloise des Sciences Naturelles 71: 63-122.

Brooks D.R., Mayes M.A. 1978: Acanthobothrium electricolum sp. n. and A. lintoni Goldstein, Henson, and Schlicht 1969 (Cestoda: Tetraphyllidea) from Narcine brasiliensis (Olfers) (Chondrichthyes: Torpedinidae) in Colombia. J. Parasitol. 64: 617-619.

Caira J.N., Burge A.N. 2001: Three new species of Acanthoboth rium (Cestoda: Tetraphyllidea) from the ocellate electric ray, Diplobatis ommata, in the Gulf of California, Mexico. Comp. Parasitol. 68: 52-65.

Caira J.N., Jensen K., Barbeau E. 2019: Global Cestode Database. World Wide Web electronic publication. www.tapewormdb.uconn.edu. Accessed August 15, 2019.

Caira J.N., Jensen K., Ivanov V.A. 2017: Onchoproteocephalidea II Caira, Jensen, Waeschenbach, Olson \& Littlewood, 2014 In: J.N. Caira and K. Jensen (Eds.), Planetary Biodiversity Inventory (2008-2017): Tapeworms from Vertebrate Bowels of the Earth. University of Kansas, Natural History Museum, Special Publication No. 25, pp. 279-304.

Caira J.N., Jensen K., Waeschenbach A., Olson P.D., LitTLEWOOD D.T.J. 2014: Orders out of chaos - molecular phylogenetics reveals the complexity of shark and stingray tapeworm relationships. Int. J. Parasitol. 44: 55-73.

Caira J.N., Reyda F.B., Mega J.D. 2007: A revision of Megalonchos Baer \& Euzet, 1962 (Tetraphyllidea: Onchobothriidae), with the description of two new species and transfer of two species to Biloculuncus Nasin, Caira \& Euzet, 1997. Syst. Parasitol. 67: 211-223.

Caira J.N., Ruhnke T.R. 1991: A comparison of scolex morphology between the plerocercoid and the adult of Calliobothrium verticillatum (Tetraphyllidea: Onchobothriidae). Can. J. Zool. 69: 1484-1488.

Campbell R.A., Beveridge I. 2002: The genus Acanthobothrium (Cestoda: Tetraphyllidea: Onchobothriidae) parasitic in Australian elasmobranch fishes. Invertebr. Syst. 16: 237-344.

Chervy L. 2009: Unified terminology for cestode microtriches: a proposal from the International Workshops on Cestode Systematics in 2002-2008. Folia Parasitol. 56: 199-230.

Clopton R.E. 2004: Standard nomenclature and metrics of plane shapes for use in gregarine taxonomy. Comp. Parasitol. 71: 130 140.

Darriba D., Taboada G.L., Doallo R., Posada D. 2012: jModelTest 2: more models, new heuristics and parallel computing. Nat. Meth. 9: 772.

Eudy E., Caira J.N., Jensen K. 2019: A new species of Pentaloculum (Cestoda: "Tetraphyllidea") from the Taiwan saddled carpetshark, Cirrhoscyllium formosanum (Orectolobiformes: Parascylliidae). J. Parasitol. 105: 303-312.

Franzese S., Ivanov V.A. 2018: Hyperapolytic species of Acanthobothrium (Cestoda: Onchoproteocephalidea) from batoids off Argentina. Parasitol. Int. 67: 431-443.

FyleR C.A. 2007: Comparison of microthrix ultrastructure and morphology on the plerocercoid and adult scolex of Calliobothrium cf. verticillatum (Tetraphyllidea: Onchobothriidae). J. Parasitol. 93: 4-11.

Fyler C.A. 2011: An extremely hyperapolytic Acanthobothrium species (Cestoda: Tetraphyllidea) from the Japanese wobbegong, Orectolobus japonicus (Elasmobranchii: Orectolobiformes) in Taiwan. Comp. Parasitol. 78: 4-14.

Goldstein R.J., Henson R.N., Schlicht F.G. 1968: Acanthobothrium lintoni sp. n. (Cestoda: Tetraphyllidea) from the elec- 
tric ray, Narcine brasiliensis (Olfers) in the Gulf of Mexico. Zool. Anz. 181: 435-438.

Guindon S., Gascuel O. 2003: A simple, fast, and accurate algorithm to estimate large phylogenies by maximum likelihood. Syst. Biol. 52: 696-704.

JENSEN K. 2005: A monograph on the Lecanicephalidea (Platyhelminthes, Cestoda). Bull. Univ. Nebr. State Mus. 18: 1-241.

Jensen K., Caira J.N., Cielocha J.J., Littlewood D.T.J., WAESCHENBACH A. 2016: When proglottids and scoleces conflict: phylogenetic relationships and a family-level classification of the Lecanicephalidea (Platyhelminthes: Cestoda). Int. J. Parasitol. 46: 291-310.

Jensen K., Cielocha J.J., Herzog K.S., Caira J.N. 2017: Lecanicephalidea Hyman, 1951. In: J.N. Caira and K. Jensen (Eds.), Planetary Biodiversity Inventory (2008-2017): Tapeworms from Vertebrate Bowels of the Earth. University of Kansas, Natural History Museum, Special Publication No. 25, pp. 207-229.

Jensen K., Nikolov P., Caira J.N. 2011: A new genus and two new species of Anteroporidae (Cestoda: Lecanicephalidea) from the darkspotted numbfish, Narcine maculata (Torpediniformes: Narcinidae), off Malaysian Borneo. Folia Parasitol. 58: 95-107.

Last P.R., White W.T., de Carvalho M.R., Séret B., StehMANn M.F.W., NAYLOR G.J.P. 2016: Rays of the World. Cornell University Press, Ithaca, $790 \mathrm{pp}$.

Littlewood D.T.J., Curini-Galletti M., Herniou E.A. 2000: The interrelationships of Proseriata (Platyhelminthes: Seriata) tested with molecules and morphology. Mol. Phylogenet. Evol. 16: 449-466.

Lockyer A.E., Olson P.D., Littlewood D.T.J. 2003: Utility of complete large and small subunit rRNA genes in resolving the phylogeny of the Neodermata (Platyhelminthes): implications and a review of the cercomer theory. Biol. J. Linn. Soc. 78: $155-171$.

Maleki L., Malek M., Palm H.W. 2019: Five new species of Acanthobothrium (Cestoda: Onchoproteocephalidea) from the long-tailed butterfly ray, Gymnura cf. poecilura (Elasmobranchii: Gymnuridae), from the Persian Gulf and Gulf of Oman. Zootaxa 4609: 289-307.

Maleki L., Malek M., Rastgoo A. 2018: Acanthobothrium chabahariensis n. sp. (Cestoda: Onchoproteocephalidea) in the cowtail stingray Pastinachus cf. sephen (Myliobatiformes: Dasyatidae) from the Gulf of Oman, Iran. J. Genet. Resour. 4 114-121.

Marques F., Centritto R., Stewart S.A. 1997: Two new species of Acanthobothrium in Narcine entemedor (Rajiformes: Narcinidae) from the northwest coast of Guanacaste Peninsula, Costa Rica. J. Parasitol. 83: 927-931.

Mojica K.R., Jensen K., Caira J.N. 2013: Revision of Anteropo$r a$ (Cestoda: Lecanicephalidea) and descriptions of five new spe- cies from stingrays (Myliobatiformes: Dasyatidae) in Borneo. Raffles Bull. Zool. 61: 491-506.

Olson P.D., Cribb T.H., Tkach V.V., Bray R.A., Littlewood D.T. 2003: Phylogeny and classification of the Digenea (Platyhelminthes: Trematoda). Int. J. Parasitol. 33: 733-755.

Pickering M., Caira J.N. 2012: A new hyperapolytic species, Trilocularia eberti sp. n. (Cestoda: Tetraphyllidea), from $\mathrm{Sq}$ ualus cf. mitsukurii (Squaliformes: Squalidae) off South Africa with comments on its development and fecundity. Folia Parasitol. 59: 107-114.

Pickering M., Caira J.N. 2013: Differences in microthrix form between stomach and spiral intestine stages of the cestode, Trilocularia: interspecific variation or development? J. Parasitol. 99: 1099-1105.

RiSER N.W. 1955: Studies on cestode parasites of sharks and skates. J. Tenn. Acad. Sci. 30: 265-311.

Rodríguez-Ibarra E., Pulido-Flores G., ViolanTe-GonzÁlez J., Monks S. 2018: A new species of Acanthobothrium (Eucestoda: Onchobothriidae) in Aetobatus cf. narinari (Myliobatidae) from Campeche, México. Rev. Bras. Parasitol. V. 27: 66-73.

Subhapradha C.K. 1955: Cestode parasites of fishes of Madras Coast. Ind. J. Helminthol. 7: 41-132.

Sukumaran J., Holder M.T. 2010: DendroPy: a Python library for phylogenetic computing. Bioinformatics 26: 1569-1571.

Tкасh V.V., Littlewood D.T.J., Olson P.D., Kinsella J.M., SwidersKi Z. 2003: Molecular phylogenetic analysis of the Microphalloidea Ward, 1901 (Trematoda: Digenea). Syst. Parasitol. 56: $1-15$.

Williams H.H. 1962: Acanthobothrium sp. nov. (Cestoda: Tetraphyllidea) and a comment on the order Biporophyllaeidea. Parasitology 52: 67-76.

Yamaguti S. 1934: Studies on the helminth fauna of Japan. Part 4. Cestodes of fishes. Jpn. J. Zool. 6: 1-112.

Yamaguti S. 1952: Studies on the helminth fauna of Japan. Part 49. Cestodes of fishes, II. Acta Med. Okayama 8: 1-76.

Yamaguti S. 1959: Systema Helminthum. Volume II. The Cestodes of Vertebrates. Interscience Publishers, Inc., New York, $860 \mathrm{pp}$.

Zaragoza-Tapia F., Pulido-Flores G., Violante-González J., Monks S. 2019: Two new species of Acanthobothrium Blanchard, 1848 (Onchobothriidae) in Narcine entemedor Jordan \& Starks, 1895 (Narcinidae) from Acapulco, Guerrero, Mexico. Zookeys 852: 1-21.

ZwICKL D.J. 2006: Genetic algorithm approaches for the phylogenetic analysis of large biological sequence datasets under the maximum likelihood criterion. Doctoral dissertation, University of Texas at Austin. 